\title{
NIGERIA AND THE COVID-19 PANDEMIC: A HISTORICAL ANALYSIS OF LEADERSHIP, POLITICS AND THE ECONOMY
}

\author{
Esamagu, Efe Emmanuel ${ }^{1}$, Martha Ezekiel Shemang ${ }^{2}$ and Progress Dakol Adanchin ${ }^{3}$ \\ ${ }^{1 \& 3}$ Department of History and International Studies, University of Jos, Plateau State, Nigeria. \\ ${ }^{2}$ Department of History, Kaduna State College of Education, Gidan-Waya, Kafanchan, \\ Kaduna State, Nigeria.
}

Correspondence: Esamagu, Efe Emmanuel, Department of History and International Studies, University of Jos, Plateau State, Nigeria.

E-mail: efemenaee@gmail.com

Phone Number: +2348060235608 .

\begin{abstract}
Prior to the current pandemic, Nigeria has witnessed the emergence of other viruses which were contained. Science is yet to proffer complete solution to this new wave of virus known as Covid-19, and the magnitude on other aspects of life is far reaching. Despite negative predictions and a wobbling health sector, the number of casualties due to the pandemic has been relatively low. Researchers are researching to find a vaccine to the virus which has culminated in the death of thousands all over the world. This study attempts to examine issues related to leadership, politics and economic policy within the context of the pandemic. The paper argues that one major problem Nigeria grapples with is leadership deficit which inevitably has affected our disposition and response to emergencies. The aforementioned can be adduced to failure of leadership to invest heavily in the health sector over the years, which is the sole responsibility of government. The study also examined the politics involved in the Covid-19 and how the economy has been affected thus far. It stressed the need for leaders to prioritize transparency and accountability while there should be a clear demarcation between politics and reality. It also buttresses the need for speedy economic reforms.
\end{abstract}

Keywords: Covid-19, Pandemic, Historical, Leadership, Politics, Economy. 


\section{Introduction}

The latest upheaval which has modified the history of the world, including diverse aspects of human life and existence is the Coronavirus also known as Covid-19. The emergence of the virus in the Asian continent, specifically China in the year 2019 gradually permeated and heightened fear of survival among the population in the world. Africa as a continent and Nigeria in particular has been seriously affected by this virus, though with minimal death compared to other countries. This is in contradiction to various predictions of the continent having records of many deaths. It is apparent that containing the viral spread has been a herculean task for most leaders. In most parts of the world, governments were faced with an apparent tradeoff between a large number of deaths and an economic shutdown. ${ }^{1}$ The norm in civilized societies is for leaders to learn from the successes and failures of their predecessors, which is historical antecedent. However, the current scourge has exposed the failure of our political leaders, the bane of leadership and our collective unpreparedness in Nigeria for emergencies. This study offers an indepth analysis and juxtaposition of leadership, politics and economic policy vis-à-vis the Covid-19 Pandemic.

\section{Leadership in Nigeria and Preparedness for Emergencies: Assessing theCovid-19 Combat}

The problem of Nigeria is largely having the right set of leaders and political will to steer progress and development in the country. It is obvious that leadership since the inception of democracy has been bedeviled with diverse challenges. They include corruption, nepotism, political brigandage, ethnic and religious crises, embezzlement of public funds, banditry, insurgency amongst others. Some of them could have been dealt with if these leaders were really serious about it. However, in recent years, the problem of leadership has degenerated to an alarming rate. Thus, citizens have deliberately been prevented from enjoying the dividends of democracy. This however, does not exclude the masses from being blamed, considering the fact that these leaders emerged from the masses and those adjudged to have performed poorly have not in the true sense of the word been recalled. A thorough assessment of the pandemic brings to the fore that leaders at the various strata of the country were ill-prepared. Madueke, Ololo and Emmanuel were lucid in their expression that "the measures put in place to curtail the adverse shock of the deadly virus have exposed Nigerian government inefficiencies."

The current virus threatens our existence as a people, although from the initial stage before the first index case was discovered in February $27^{\text {th }}$, 2020, a lacklustre disposition was exhibited by these leaders towards its containment. Pat in his assessment of the whole situation asserted that "if there is anything absent in Nigeria currently, it is leadership. . The nation's political class has failed to align itself to the new reality and the fact we have an existential crises." 3 The systemic collapse of the health sector is a deliberate attempt by

\footnotetext{
1 Andre Blais, Damien Bol,Marco Giani, Peter Loewen. "The Effect of COVID - 19 Lockdown on Political Support: Some Good News For Democracy". European Journal of Political Research, QPE Working Paper (2020), 1. Dol: 10. 1111/1475 - 6765. 12401. Accessed August $19^{\text {th }}, 2020$.

Matthew M. Kavanagh, Renu Singh. "Democracy, Capacity, and coercion in Pandemic Response - COVID - 19 in comparative Political Perspective". Journal of Health Politics, Policy and Law (2020), 1. Dol: 10. 1215/03616878 -8641530.

${ }^{2}$ Madueke, Onyedikachi, Ololo. Allens Iheonu and Emmanuel. Ejike. Post CoviD-19 Pandemic Nigeria: Implications for Good Governance".Journal of Public Administration and Social Welfare Research, 5, no. 2 (2020), 43-51

${ }^{3}$ Pat Utomi:. "Government in Nigerian crippled, Lacks Leadership". Vanguard, 31 August 2020. https://www.vanguardngr.com (accessed 31 August 2020).
} 
leaders who have not invested much in the system. The United Nation (UN) to which Nigeria is signatory approved fifteen percent of annual budget for countries to allocate to the health sector. This has not reflected in the yearly budget being presented, assented to and signed into law for many years. Failure to initiate the right policies in the health sector has exposed the lacuna in leadership. The current pandemic demonstrates convincingly that the right structures have not been put in place.

The fact that the current virus shares a zoonotic origin with the Ebola Virus disease (EVD) and the Zika Virus, ${ }^{4}$ more practical steps should have been taken in that direction. Nigerian leaders failed to emulate the proactive style of response of the Chinese government. Preparedness at all times and in all situations should form a fulcrum of their lives. Doyin expressed his dissatisfaction at the "disparity between the public statements about Nigeria's preparedness and the reality on ground as revealed by ordinary people." 5 Olga alluded to David's concept of "preparedness which includes for potential pandemics, requires conditional and management of complex relationships across different sectors and between international, national and local actors." $\mathrm{Ab}$ initio, most of our leaders were never prepared for leadership roles, neither do they envisage emergencies which could constitute a threat to survival and livelihood.

The inability of our leaders through the various agencies like the Ministry of Health, Nigerian Center for Disease Control (NCDC) to contain the spread of the virus lends credence to the axiom that the health sector has not been properly funded. As enshrined in the 1999 constitution of the Federal Republic of Nigeria as amended in 2011, section 17, subsection 3, article 4, "regards the provision of all other infrastructure like building hospitals as the responsibility of government."7 Our leaders do not have confidence in the health institutions they established, thus they have made medical tourism to gain prominence. Nevertheless, measures imposed in most parts of the world to contain spike in the number of cases like shutting down international airports debarred them from travelling outside the shores of the country. It is mind-boggling that in the $21^{\text {st }}$ century, many Primary Health Care (PHC) centres are in a dilapidated state. These are facilities considered the closest to the rural dwellers. The few health care workers and facilities were overstretched with Covid-19 pandemic, not to even mention the brain drain and the steady reasons adduced. This movement has snowballed to a steady hemorrhage of qualified and competent health care workers. Chikwe and Emmanuel explained "that the disproportionality in adverse outcomes may be due to the impact of health disparities, poorer access to health care, and lower socioeconomic status."

\footnotetext{
${ }^{4}$ Maffiolo. M. Elisa. "How Is The World Responding To The Novel Coronavirus Disease (COVID -19) Compared With The 2014 West African Ebola Epidemic? The Importance of China as a Player In The Global Economic". The American Society of Tropical Medicine and Hygiene, 102, no. 5 (2020), 924 - 925. Doi: 10. 4269 /ajtmh. 200135.

5 Doyin Odubanjo. "The Biggest Threats To Nigeria Managing COVID - 19: Panic, Politics and Indecision." The Conversation, (2020) https://www.the conversation.com (accessed 5 Sep. 2020).

${ }^{6}$ Olga B. Jonas. "Pandemic Risk". World Bank Report: World Development Report (2014), 1.

${ }^{7}$ Federal Republic of Nigeria, The 1999 Constitution of The Federal Republic of Nigeria As Amended (Nigeria, 1999), 34.

${ }^{8}$ Chikwe Ihekweazu, Emmanuel Agogo. “Africa’s Response To COVID -19”,BMCMedicine (2020), 1 - 3.
} 
"The pandemic has affected every aspect of our national life; but more importantly, it has also exposed the institutional weaknesses, infrastructural decay and governance failure of the country." In an era of technological advancement, Nigeria still lags behind even though we still pride ourselves as the giant of Africa. Our leaders have not really helped matters. After years of democratic leadership, the country is unable to produce simple medical equipments like Personal Protective Equipments (PPEs) and Ventilators. It is alarming that in the heat of the pandemic, frontline workers complained of shortage of these essential and life-saving equipments which resulted to the death of some of these personnels. We had to wait for China's richest man, "Jack Ma to make round of donations of medical equipments like ventilators, test kits, protective suits to aid Coronavirus fight." 10

\section{Politicization of the Covid-19 Pandemic in Nigeria}

The country is gradually returning to normalcy after the measures adopted to contain the spread of the virus. Though the pandemic is yet to be abated, but the politics which surrounded it in Nigeria raised a lot of hullabaloo concerning its reality. This affected compliance of guidelines and protocols issued by the Nigerian Centre for Disease Control (NCDC). Yusuf, Hadiza and Faruk were emphatic that "Nigerians were careless about the pandemic because of the ethical concealment of Covid-19 victims by NCDC and individual search for food to avoid hunger" "It is rather unfortunate that political leaders have not been forthright and prudent with the resources, thus giving citizens the basis to doubt them. It is now history that targeted lockdown measures were imposed in some states to contain the spread of the virus. Inevitably, it had adverse effects on the people and in a bid to cushion the effect of such decision on the people, different palliative measures were rolled out. The brouhaha associated with the distribution is indicative of a system whereby the state lacks capacity and transparency. Much noise was made about it but in the process palliatives meant to ease the suffering of the people never got to the targeted audience. Olu and Paul averred that "the public perceive the virus as non-existent but a means for the government to divert public fund to private pocket."12 "Lamentations trailed the distribution of government palliatives by the masses." 13

Politics was displayed right from the moment the first index case was discovered in Nigeria. It was imported into the country by an Italian in February $27^{\text {th }}, 2020$. Prior to this time, there were several calls by citizens to shut down international airports, stop flights and shut down

\footnotetext{
${ }^{9}$ Yusuf Abdullahi Gusau, Ahmed Hadiza, and Maiyaki Usman Faruk. "Tracking and Modelling of Public Perceptions Towards The Reality of COVID - 19 Pandemic In Nigeria”. ResearchGate (2020), 2 -3. https://www.researchgate.net/Publication/343689133(accessed 5 Sep. 2020).

${ }^{10}$ Samson Tormade, “Jack Ma Donates Ventilators, PPE To Nigeria to aid Coronavirus Fight”. Pulse Nigeria 6 April 2020.https://www.pulse.ng/news/local/coronavirus-chinese-billionaired-jack-ma-donates-ventilators-ppes-to-nigeria. (accessed 29 September, 2020).

${ }^{11}$ Yusuf Abdullahi Gusau, Ahmed Hadiza and Maiyaki Usman Faruk. "Tracking and Modelling of Public Perceptions..."

12 Olu Awofeso and Irabor Paul. A. “Assessment of Government Response to Socieconomic Impact of Covid - 19 Pandemic in Nigeria”. Journal of Social and Political Sciences, 3, no. 3 (2020), 677 - 686.

${ }^{13}$ Isaac Omo - Ehiabhi Eranga "Covid - 19 Pandemic in Nigeria: Palliative Measures and the Politics of Vulnerability". International Journal of Maternal and Child Health and Aids, 9, no. 2(2020), 220 222.https://www.mchandaids.org.(accessed 29 September, 2020).
} 
the borders. The aforementioned was to prevent the spike in the number of imported cases and the spread of the virus. The deliberate delay by the Federal Government to heed to the fears entertained by the citizens was considered political in the sense that many believed that it was meant to give room for top government functionaries and families members to return to the country. Unfortunately, some of these people who returned were already infected and due to other complications lost their lives. Even the quick reopening of international airports while there were other pending but germane issues sounded political.

Vulnerability was a phenomenon that became pronounced during the disbursement of funds meant to assuage the plight of the people as a result of the lockdown. The question that looms large and which both the Federal and state Governments are unable to answer is: "who are the vulnerable? Is it that the Federal government was unable to involve a transparent process to ensuring fair distribution of the palliatives? Is the idea of undefined vulnerability a ploy by the government to hijack the palliatives for their party faithful?. . " ${ }^{\prime 14}$ There is no updated data on the number of those classified as vulnerable. Also, one may be compelled to ask about the determining factors employed to select those who belong to this category. Political actors and their crones chose people and doted out the palliatives in a dishonest manner. Even in cases where some were given, it was just a paltry sum. In addition, it was for the sole reason of justifying the humungous amount that had been approved by government or given by international donors and organizations. During this period, many Nigerians evolved new term known as "audio palliatives". The imbroglio between the National Centre for Disease Control (NCDC) and two states (Cross River and Kogi) over the existence of the virus and the conduct of testing heightened the misconceptions among Nigerians about the reality of the virus.

Of recent is the discovery of warehouses in different states of the country. The federal government had received donations from local and international donors. The coalition against Covid-19 (CA-COVID), a private sector had collected tens of millions of dollars' worth of aid and handed it over to the government. A lot of amount was realized and the Central Bank of Nigeria $(\mathrm{CBN})$ was instructed to lodge these monies in her account. The federal government through the Ministry for Humanitarian and Disaster affairs distributed palliatives in form of bags of foodstuffs to various states. At different fora, the minister who superintends over the ministry reiterated the fact that they had been distributed. The recent discovery of the warehouses where these palliatives meant for the vulnerables had been stored by politicians confirmed her statement. This showed the insincerity of leaders expected to assuage the plight of the vulnerables. The discovery culminated in the looting of these warehouses by Nigerians and the shops of private individuals which is unjustifiable. Many believed that these foot items had been stored in preparation for 2023 elections, when they will be used for campaign, to sway the mind of the public and secure their votes. In a bid to quickly exonerate her members, the Nigeria Governors' Forum (NGF) claimed that the looted items in warehouses in some states were being held for vulnerable people and not hoarded. ${ }^{15}$ The attitude of our politicians in the heat of the pandemic coupled with unfolding events indeed confirmed the suspicion by skeptics about the existence of the virus.

\footnotetext{
${ }^{14}$ Isaac, Omo - Ehiabhi Eranga. "Covid - 19 Pandemic in Nigeria: Palliative Measures... 220 - 222.

15 Timothy Obiezu. "Nigerians Justify Massive Looting of COVID-19 Supplies". VOA News,27 October 2020. https://www.voanews .com/covid-19-pandemic/Nigerians-justify-massive-looting-covid-19(accssed 27 November, 2020).
} 


\section{Covid-19 and Economic issues in Nigeria}

The pandemic has generated economic problems in Nigeria. Ogunpola asserted that "due to the escalating global economic impact of the pandemic, many economies around the globe have witnessed reduced economic activities. With a recession looming as a result of the pandemic, that number only grow if proper measures are not enacted" ${ }^{16}$ It has been clearly adduced that "before the pandemic, the Nigerian government had been grappling with weak recovery from the 2014 oil price shock, with GDP growth tapering around 2.3 percent in 2019." ${ }^{\text {"T }}$ The Covid-19 pandemic has left in its trail enormous human, social, economic disruption and taleful woes in Nigeria. Many jobs have been lost, some companies have downsized while others have reduced the emolument of workers, amongst other issues. This stems from lack of viable economic policies to stimulate the growth and development of the economy. With our appellation as the "giant of African", the investment in the teeming population has been minimal. It is a fact that countries all over the world have been adversely affected by the measures adopted to contain the virus. Recently, the Federal government announced that Nigeria is officially in recession, the second in five years and the worst in over thirty years. How the government intends to change the current narrative is a question yet to be answered.

It is noteworthy that dependants of even meager salary earners have been adversely affected by the aftermath of the pandemic. It is unarguable that the unemployment rate has skyrocketed while states in the country have always complained of low revenue profile. Thus, governors in these states may hide under the guise of the current situation not to engage new people in the different Ministries, Departments and Agencies (MDAs) of government. The lesson derived from the current scenario is the need to regularly build the capacity of the indigent populace with necessary skills through the organization of skills acquisition programmes. Soji's assertion is a validation of the above fact "that the scare brought into sharp focus the mistakes and failures of the past, it has reinforced more than ever before the imperative of urgently and vigorously pursuing a new raft of ideas and action plans that should seek to release our people from the stranglehood of poverty and disease, re-energize our national economy,..."18 There is no better time than now to uplift the standard of living of the people and to initiate the right economic policies. Most importantly, social and economic disparities which have been visible for years need to be addressed.

\section{Conclusion}

\footnotetext{
${ }^{16}$ Ogunpolu Tobiloba, "From Pandemic to Poverty: Nigeria's Future with COVID - 19”, Nairametrics, 17 May 2020. https://www.nairametrics.com/2020(accessed 21 October

${ }^{17}$ Onyekwena Chukwuka, and Ekeruche Amara Mma, "Under-standing the Impact of the COVID - 19 Outbreak on The Nigerian Economy”, Brookings, 8 April 2020.https://www.brookings.edu/blog/Africa-infocus/2020/04/08/understanding(accessed 21 October, 2020).

${ }^{18}$ Soji Ehinlawo. "Nigeria: Deploying Lessons Learnt and Resetting Priorities For A Post-COVID-19 Nigeria”. Premium

Times, 18 May 2020. https://www.premiumtimes.ng.com(accessed 30 September, 2020).
} 
This paper explored the issues of leadership, politics and the economy in relation to the Covid-19 pandemic in Nigeria. It clearly identified the lacuna in leadership and the fact that over the years the health sector has not been properly funded. Ipso facto, this article posited that it is pertinent for leaders at the various strata of the country to ensure a robust health system. The system should be reinvigorated with more health care workers who possess requisite skills and experience. Leaders must expedite action on the provision of affordable health care services to the Nigerian populace. Leaders should be able to divorce politics from reality and important issues should not be politicized especially issues of national concern which poses threat to the existence of humans. Government must ensure virile policies to stimulate the growth and development of the economy in order to avoid the predicament we found ourselves during the pandemic. 


\section{Bibliography}

Andre Blais, Damien Bol, Marco Giani, Peter Loewen. "The Effect of COVID -19 Lockdown on Political Support: Some Good News For Democracy". European Journal of Political Research, QPE Working Paper (2020). Dol: 10.1111/14756765.12401(accessed 19 August, 2020).

Chikwe Ihekweazu, Emmanuel Agogo. “Africa's Response To COVID -19”. BMC Medicine (2020).

Doyin Odubanjo. "The Biggest Threat to Nigeria Managing COVID - 19: Panic, Politics and Indecision. The Conversation (2020), https://www.theconversation.com(accessed 5 September, 2020).

Federal Government of Nigeria, The 1999 Constitution of The Federal Republic of Nigeria As Amended in 2011 (Nigeria, 1999).

Isaac Omo - Ehiabhi Eranga. "Covid - 19 Pandemic in Nigeria: Palliative Measures and the Politics of vulnerability". International Journal of Maternal and Child Health and Aids, 9 no. 2(2020).https://www.mchandaids.org(accessed 29 September, 2020).

Madueke Onyedikachi, Ololo Allens Iheonu, Emmanuel Ejike. "Post COVID -19 Pandemic Nigeria: Implications For Good Government". Journal of Public Administration Administration and Social Welfare Research, 5, no. 2 (2020).

Maffiolo. M. Elisa. "How is the World Responding To The Novel Coronavirus Disease (COVID-19) Compared With the 2014 West African Ebola Epidemic?. The Importance of China as a Player in the Global Economy". The American Society of Tropical Medicine and Hygiene, 102, no. 5 (2020). Doi:10.4269/ajtmh.200135.

Matthew. M. Kavanagh, Renu Singh. "Democracy, Capacity and coercion in Pandemic Response-COVID-19 in Compaarative Political Perspective". Journal of Health Politics, Policy and law(2020). Doi:10.1215/03616878-8641530.

Ogunpoly Tobiloba. "From Pandemic to Poverty: Nigeria's Future With COVID - 19". Nairametrics, 17 May 2020. https:www.nairametrics.com/2020 (accessed 21 October, 2020).

Olga. B. Jonas. “Pandemic Risk”. World Bank Report: World Development Report (2014).

Olu Awofeso, Irabor Paul. A. "Assessment of Government Response to Socioeconomic Impact of Covid-19 Pandemic in Nigeria". Journal of Social and Political Sciences, 3. No. 3 (2020).

Onyekwena Chukwuka, Ekeruche Amara Mma. "Understanding The Impact of the COVID19 Outbreak on The Nigerian Economy", $\underline{\text { Brookings, }} 8$ April2020.https//www.brookings.edu/blog/Africa-in-focus/2020/04/08/understanding (accessed 21 October, 2020).

Pat Utomi. "Government in Nigeria Crippled, Lacks Leadership". Vanguard, 31 August 2020. https://www.vanguargngr.com(accessed 31 August 2020). 
Samson Toromade. "Jack Ma Donates Ventilators, PPE To Nigeria to aid Coronavirus Fight". Pulse Nigeria, 6 April 2020.https://www.pulse.ng/news/local/coronaviruschinese-billionaire-jack-ma-donates-ventilators-ppes-tonigeria(accessed September, 2020).

Soji Ehinlawo. "Nigeria: Deploying Lessons Learnt and Resetting Priorities For a PostCOVID-19 Nigeria". Premium Times, 18 May 2020.https://www.premiumtimes.ng.com(accessed 30 September, 2020).

Timothy Obiezu. "Nigerians Justify Massive Looting of COVID-19 Supplies". VOA News, 27 October 2020. https//www.voanews.com/covid-19-pandemic/nigerians-justifymassive-looting -covid-19(accessed 27 November, 2020).

Yusuf Abdullahi Gusau, Ahmed Hadiza, Maiyaki Usman Faruk. "Tracking and Modelling of Public Perceptions To-wards The Reality of COVID-19 Pandemic in Nigeria". ResearchGate (2020). https://www.researchagate.net/publication/343689133 (accessed 5 September 2020) 